\title{
Amphiphilic dendritic peptides: Synthesis and behavior as an organogelator and liquid crystal
}

\author{
Baoxiang Gao*, Hongxia Li, Defang Xia, Sufang Sun and Xinwu Ba
}

\author{
Letter \\ Address: \\ Key Laboratory of Medicinal Chemistry and Molecular Diagnosis, \\ Ministry of Education, College of Chemistry and Environment \\ Science, Hebei University, Baoding 071002, P.R. China \\ Email: \\ Baoxiang Gao* - bxgao@hbu.edu.cn \\ * Corresponding author \\ Keywords: \\ amphiphilic; dendritic peptides; liquid crystal; organogels
}

\author{
Beilstein J. Org. Chem. 2011, 7, 198-203. \\ doi:10.3762/bjoc.7.26 \\ Received: 02 November 2010 \\ Accepted: 09 January 2011 \\ Published: 11 February 2011 \\ Editor-in-Chief: J. Clayden \\ (C) 2011 Gao et al; licensee Beilstein-Institut. \\ License and terms: see end of document.
}

\begin{abstract}
New amphiphilic dendritic peptides on dendritic polyaspartic acid were designed and synthesized. The organogel and liquid crystal properties of these amphiphilic dendritic peptides were fully studied by field-emission SEM, temperature dependent FT-IR, differential scanning calorimetry, polarization optical microscopy and X-ray diffraction experiments. Amphiphilic dendritic peptides G3 show good organogel properties with a minimum gelation concentration as low as $1 \mathrm{wt} \%$. Furthermore, amphiphilic dendritic peptides $\mathbf{G 3}$ can form a hexagonal columnar liquid crystal assembly over a wide temperature range.
\end{abstract}

\section{Introduction}

Peptide self-assembly has drawn a significant attention due to potential applications, especially in the fields of biomedicine and bionanotechnology [1-3]. Programmed self-assembly of peptides into highly ordered nanostructures creates biomaterials that display a wide range of physical properties often exceeding those of synthetic polymers [4,5]. Peptideamphiphiles (PAs) represent an attractive class of bioactive molecules as they self-assemble into a variety of nanostructures, many of which have promising biological activity due to the exposed peptide regions on their outer surface [6,7]. The selfassembly of amphiphilic oligopeptide systems is thus emerging as a particularly powerful strategy to direct the self-assembly of relatively simple peptide building blocks toward sophisticated nanostructures [8]. Furthermore, the natural amino acid based dendrons or dendrimers are of great significance because of their similarity to proteins in composition and topology [9-11], as well as their architectural difference from currently prevalent linear model peptides. However, little attention has been paid to the self-assembly of natural amino acid based dendrimers, and especially to their gelation and liquid crystal properties [12,13]. Recently, a type of amphiphilic dendritic dipeptide was described by Percec et al. as self-assembling in helical pores 
[14]. In addition, Takashi Kato and co-workers have recently reported that dendritic oligopeptides can act as useful building blocks for chiral supramolecular liquid crystals $[15,16]$.

Herein, we present the synthesis of amphiphilic dendritic peptides (ADPs) composed of an aspartic acid core and an aliphatic periphery, and their self-assembly which leads not only to organogels but also to liquid crystals.

\section{Results and Discussion Synthesis and characterization}

The amphiphilic dendritic peptides were synthesized convergently as depicted in Scheme 1 via standard EDCI coupling of $N$-carbobenzyloxy-L-aspartic acid and L-aspartic acid dodecyl ester (readily prepared by the esterification of aspartic acid with 1-dodecanol). The second (G2) and third generations (G3) were synthesized convergently in 75 and $60 \%$ yields, respectively, by repeating a two-reaction cycle, i.e., by removal of the carbobenzyloxy group of the lower-generation dendron by hydrogenation, and then coupling the resulting $N$-deprotected intermediate to the $C$-deprotected G1, prepared by hydrogenolysis of the benzylated peptide. ${ }^{1} \mathrm{H}$ NMR, MALDI-TOF mass spectrometry, and elemental analyses were used to verify the structure and purity of the amphiphilic dendritic peptides.

\section{Investigation of gelation}

All amphiphilic dendritic peptides were subjected to gelation tests in a variety of organic solvents. Each compound was combined with solvent in a screw-capped sample tube and heated until the solid completely dissolved. The solution was then cooled to room temperature, and gelation monitored by inverting the sample tube to see whether the solution flows or not. The observed gelation behavior of each solution is summarized in Table 1. Compound G1 showed good solubility in a range from non-polar ( $n$-hexane) to polar solvents (ethanol), and showed no gelation in any solvent tested. Compound G2 can gel only in the nonpolar $n$-hexane. Compound G3 gelled in $n$-hexane, toluene, 1,4-dioxane, and ethanol but was soluble in dichloromethane.

The microscopic structure of the gel was investigated by fieldemission SEM (FE-SEM). Figure 1 shows representative

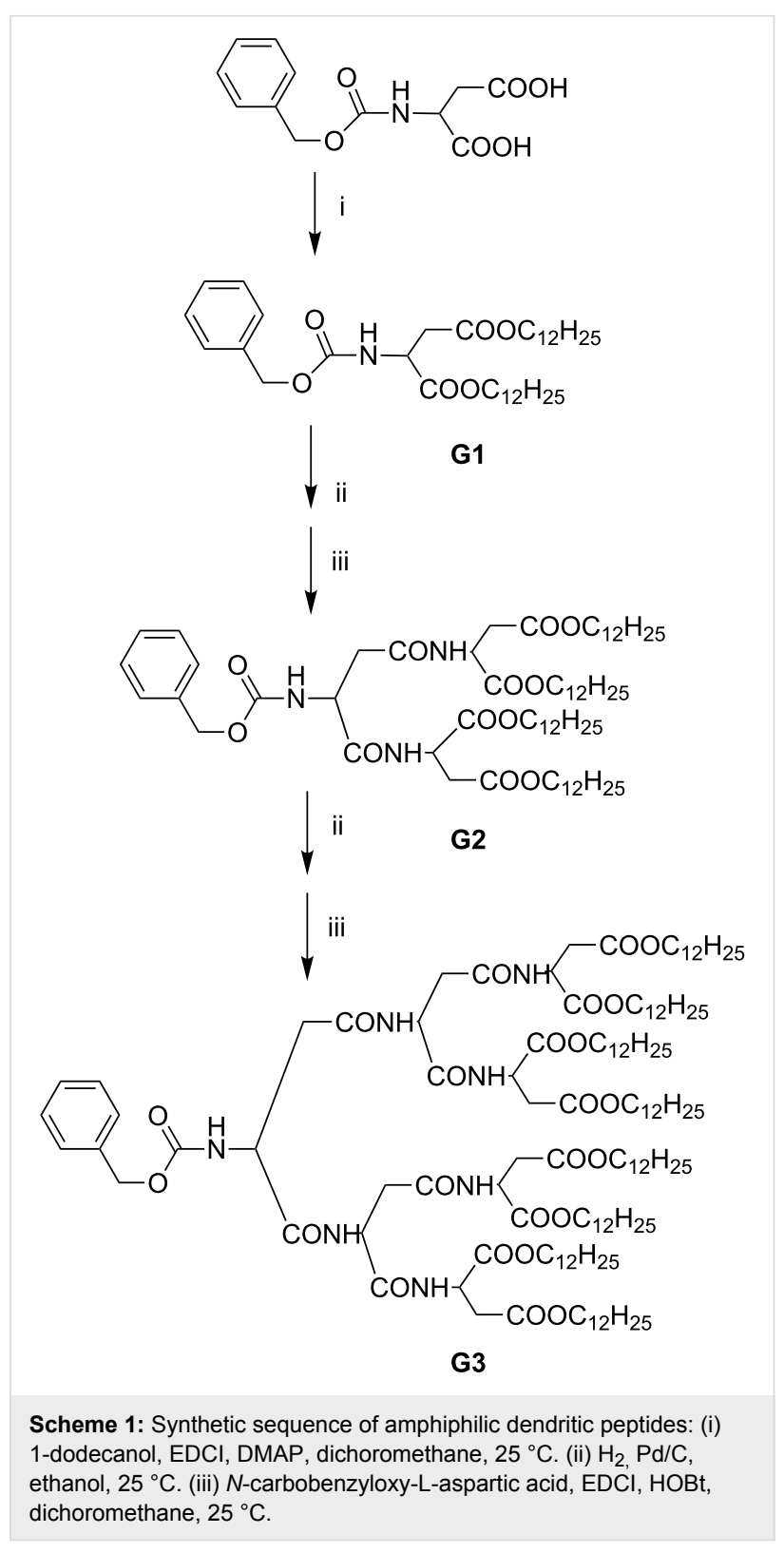

FE-SEM images of the xerogel of $\mathbf{G 3}$ formed in $n$-hexane. These images clearly show that organogels assembled from G3 formed thin fibres that underwent further aggregation to form fibre bundles. These fibre bundles constitute a highly developed entangled network.

\begin{tabular}{|c|c|c|c|c|c|}
\hline & $n$-hexane & toluene & dichloromethane & 1,4-dioxane & ethanol \\
\hline G1 & S & S & S & S & $\mathrm{S}$ \\
\hline G2 & $\mathrm{G}(\mathrm{cgc}=3 \%)$ & $S$ & $S$ & $S$ & S \\
\hline G3 & $G(\operatorname{cgc}=1 \%)$ & $\mathrm{G}(\mathrm{cgc}=5 \%)$ & $S$ & $\mathrm{G}(\mathrm{cgc}=6 \%)$ & $G(\operatorname{cgc}=2 \%)$ \\
\hline
\end{tabular}

${ }^{\mathrm{a}} \mathrm{cgc}$ : gelation concentration (w/w \%). G: gel. S: solution. 


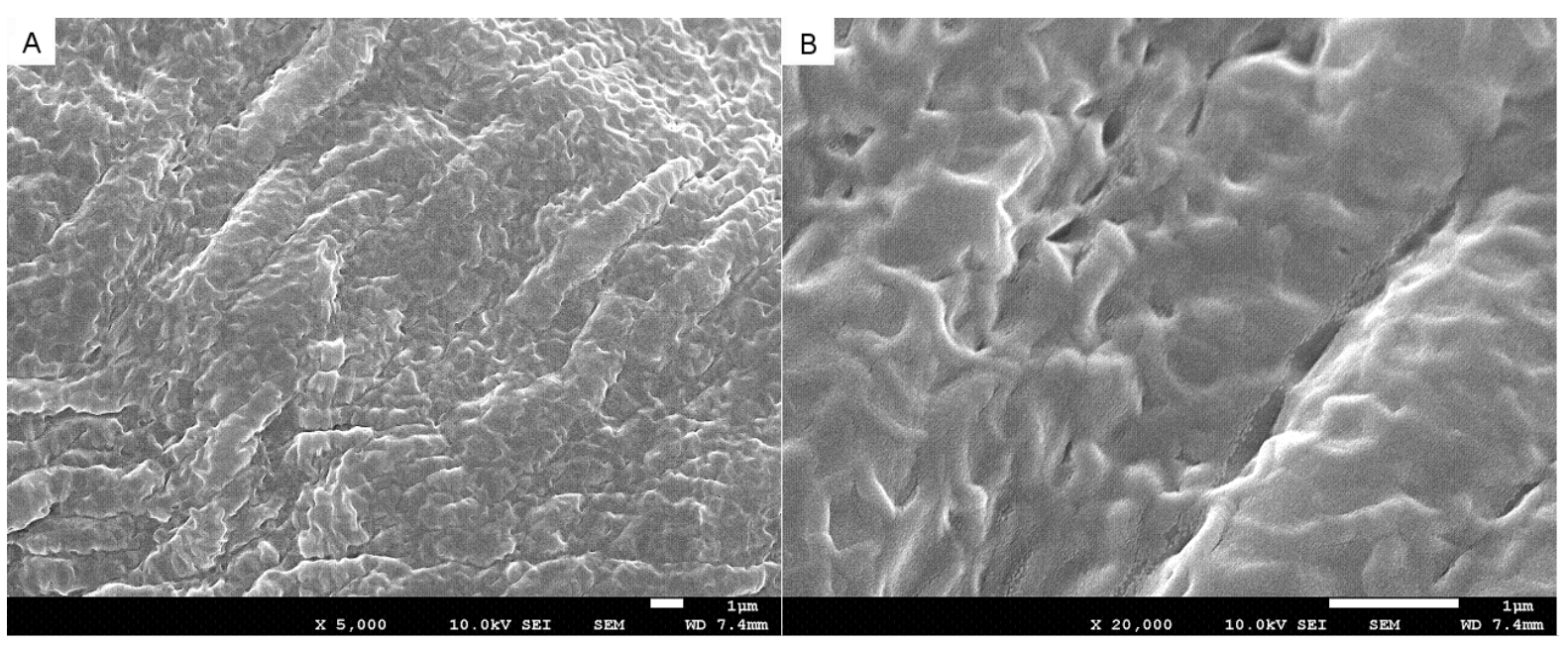

Figure 1: (A) SEM images of the xerogels of G3 from $n$-hexane (B) magnification of the xerogels structure.

Figure 2 shows the XRD scan of organogelator $\mathbf{G 3}$ and liquid crystal G3. Being different from the liquid crystal, the XRD of organogelator shows no reflection peaks in the small-angle region which indicates that molecular arrangement in the organogelator is disordered. Figure 3 shows the FT-IR of G3 as an organogelator and as a liquid crystal. The absorption at 3081 $\mathrm{cm}^{-1}$ is ascribed to the $\mathrm{N}-\mathrm{H}$ stretching frequency of the hydrogen bonds. The absorption intensity at $3081 \mathrm{~cm}^{-1}$ decreases in the organogelator which indicates the loss of hydrogen bonds.

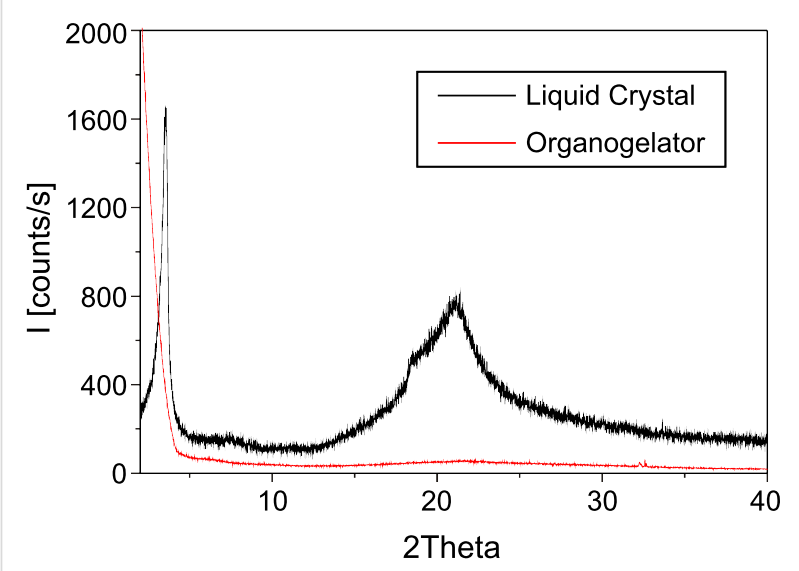

Figure 2: X-ray diffraction patterns of $\mathbf{G} 3$ as an organogelator and liquid crystal.

Hydrogen bonds as physical cross-linking points in these compounds are an essential factor for gelling. With more physical cross-linking points, compound $\mathbf{G 3}$ gels more easily. Compound $\mathbf{G} 2$ can gel only in $n$-hexane. Compared with the other solvents, $n$-hexane is a poor solvent, in

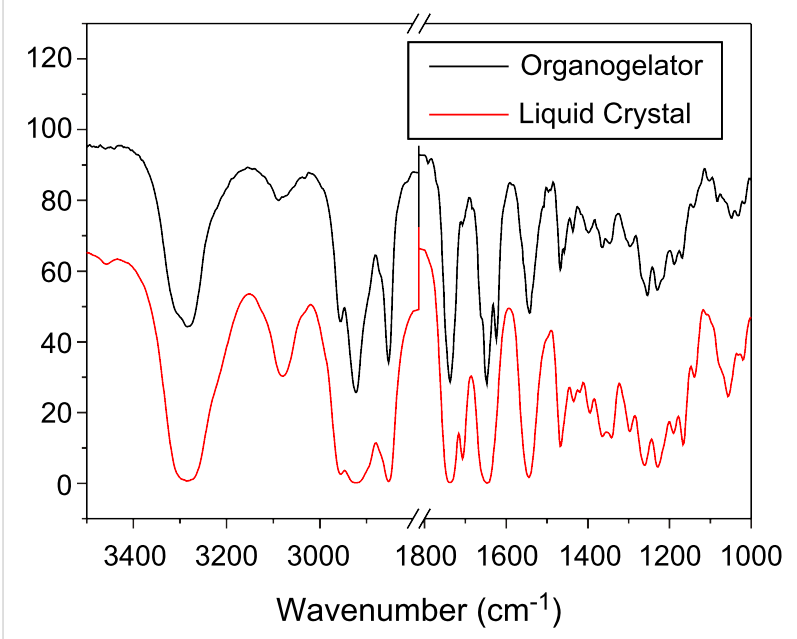

Figure 3: FT-IR of G3 as an organogelator and liquid crystal.

which hydrogen bonds form more easily. It is therefore reasonable that the minimum gelation concentration of G3 (1 wt \%) was lower than G2 (3 wt \%) in the same (n-hexane) solvent.

\section{Investigation of the liquid crystalline behavior}

Thermotropic behavior of ADPs was investigated by a combination of differential scanning calorimetry (DSC), polarization optical microscopy (POM) and X-ray diffraction (XRD) experiments. Figure 4 shows DSC curves of amphiphilic dendritic peptides. In the DSC scan from $-60{ }^{\circ} \mathrm{C}$ to $200{ }^{\circ} \mathrm{C}, \mathbf{G 1}$ showed three phase transitions at $15{ }^{\circ} \mathrm{C}, 25{ }^{\circ} \mathrm{C}$ and $40{ }^{\circ} \mathrm{C}$, which are attributed to phase transitions of recrystallization and crystal to isotropic melt. $\mathbf{G 2}$ only showed a phase transitions at $71^{\circ} \mathrm{C}$, which is attributed to the phase transition of crystal to 
isotropic melt. DSC analysis of $\mathbf{G 3}$ showed phase behavior, where a LC mesophase, on a second cooling, appeared at $40{ }^{\circ} \mathrm{C}$ and then disappeared at $145^{\circ} \mathrm{C}$ to form an isotropic melt (Figure 4). The high temperature for the isotropic melt of $\mathbf{G 3}$ is the result of hydrogen bond interactions of the amide groups which reinforce the columnar organization.

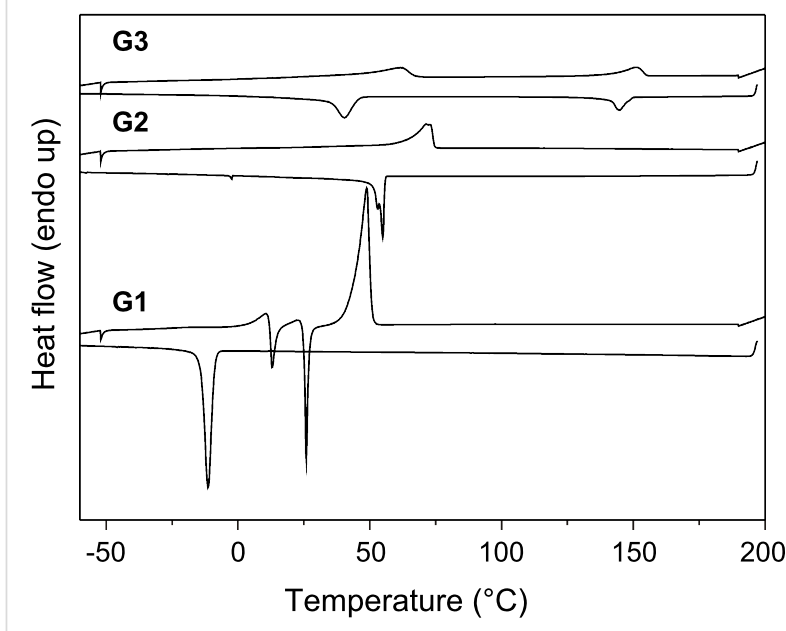

Figure 4: Differential scanning thermograms of ADPs registered during the second heating-cooling cycle with scanning rate $10 \mathrm{~K}$ $\min ^{-1}$.

The presence of hydrogen bonds in the liquid-crystalline phases of $\mathbf{G 3}$ is demonstrated by temperature dependent FT-IR studies (Figure 5). Cooling from $160{ }^{\circ} \mathrm{C}$ (isotropic state) to $20{ }^{\circ} \mathrm{C}$ (liquid crystalline state), the absorption intensities of the free amide groups at $1685 \mathrm{~cm}^{-1}$ decrease. The absorption intensities of the hydrogen bonding amide groups $1648 \mathrm{~cm}^{-1}$ increase. Furthermore, the $\mathrm{N}-\mathrm{H}$ stretching frequency of $\mathbf{G 3}$ shifts from $3354 \mathrm{~cm}^{-1}\left(160{ }^{\circ} \mathrm{C}\right)$ to $3288 \mathrm{~cm}^{-1}\left(20^{\circ} \mathrm{C}\right)$, and the absorption intensities at $3084 \mathrm{~cm}^{-1}$ (the $\mathrm{N}-\mathrm{H}$ streching frequency of the hydrogen bonds) also increase which indicates that hydrogen bonds form in liquid crystalline. With the high selectivity and directionality of hydrogen bonds, the formation of the hydrogen bonds should contribute to the columnar liquid crystalline properties.

Cooling from $160{ }^{\circ} \mathrm{C}$ to $145^{\circ} \mathrm{C}, \mathbf{G 3}$ begins to form the conic fan-shaped textures (Figure 6A), which are characteristic of hexagonal columnar liquid crystals. The conic fan-shaped textures of $\mathbf{G} 3$ grow (Figure $6 \mathrm{~B}$ ), and no longer change at $50{ }^{\circ} \mathrm{C}$ (Figure 6C). Figure 7 shows the XRD scan for the birefringent phase of $\mathbf{G 3}$ at $50{ }^{\circ} \mathrm{C}$. The birefringent phases of $\mathbf{G 3}$ were further confirmed as a hexagonal columnar liquid crystal phase through assignment of the reflections. In the wide angle region, the diffused halo at around $4.5 \AA$ is due to the disorder of the

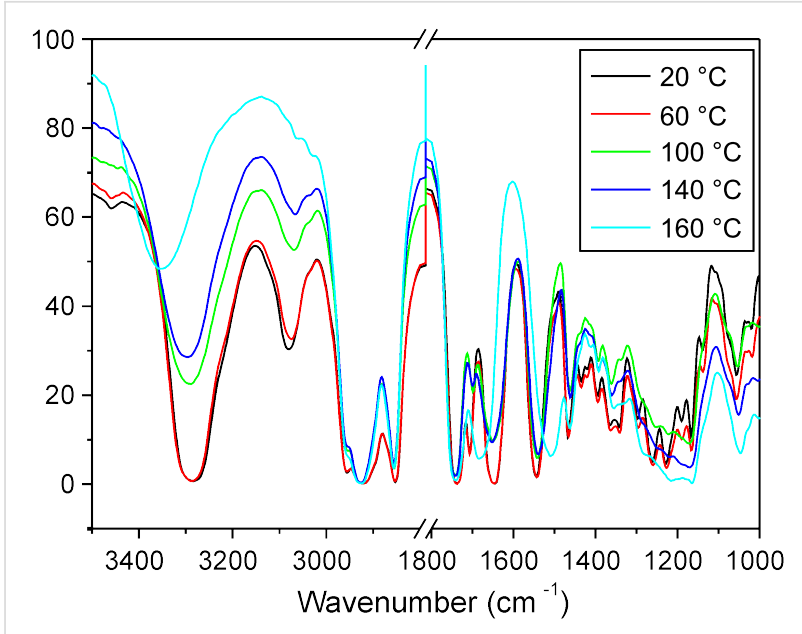

Figure 5: Temperature dependent FT-IR of G3.
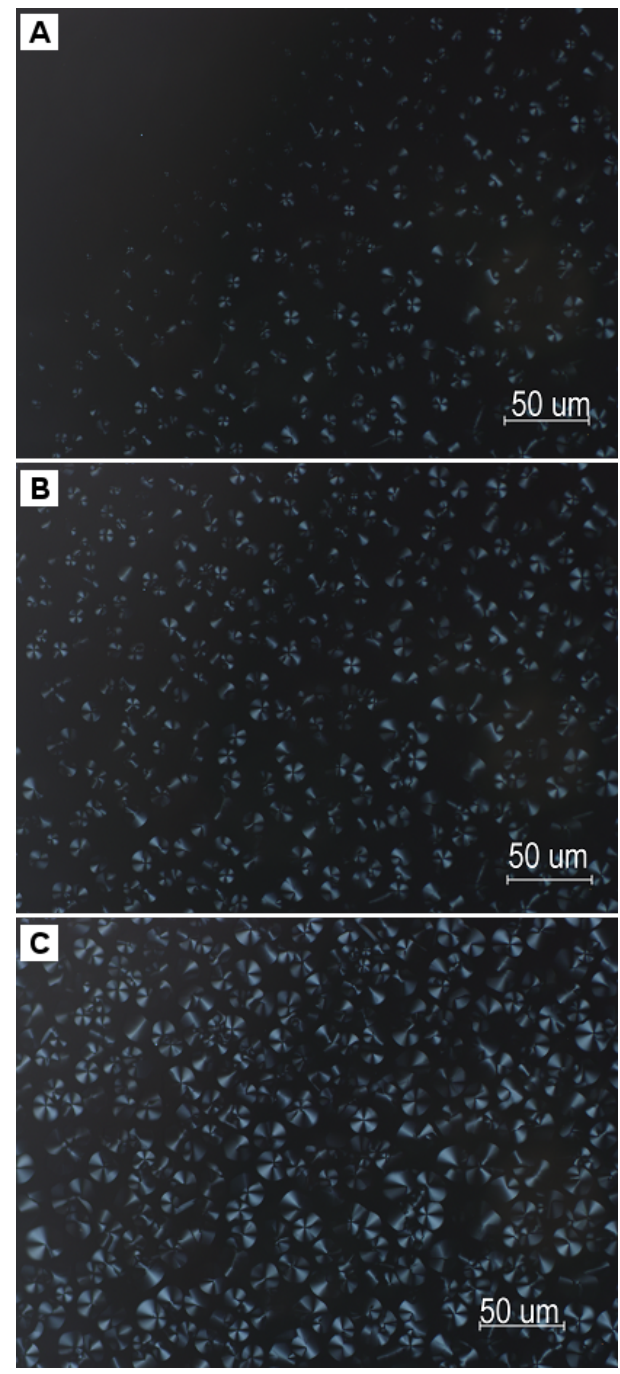

Figure 6: . Polarized optical micrographs of $\mathbf{G} 3$ at $145^{\circ} \mathrm{C}(\mathrm{A}), 140{ }^{\circ} \mathrm{C}$ (B), and $50^{\circ} \mathrm{C}(\mathrm{C})$. 


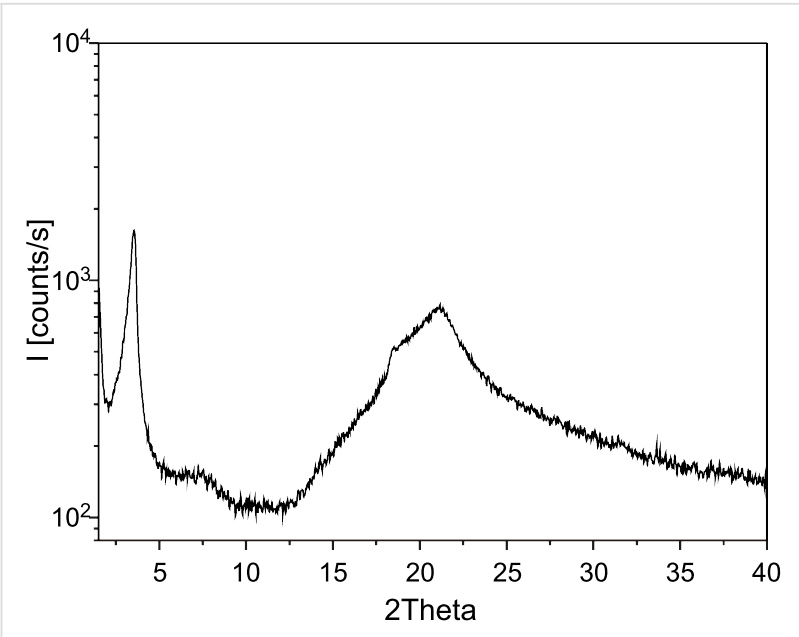

Figure 7: X-ray diffraction patterns of $\mathbf{G} 3$ at $50{ }^{\circ} \mathrm{C}$.

terminal alkyl chains. In the small-angle region, the XRD profile of $\mathbf{G} 3$ shows two reflection peaks corresponding to d spacing of 24.8 and 12.5 corresponding to (100) and (200) reflections. The XRD results show the compound G3 selfassembles into columnar structures.

\section{Conclusion}

In summary, we designed and synthesized amphiphilic peptides on dendritic polyaspartic acid. These new amphiphilic dendritic peptides are capable of gelling a variety of organic solvents to form stable organogels via cooperative non-covalent forces, with a minimum gelation concentration as low as $1 \mathrm{wt} \%$. It is interesting that amphiphilic dendritic peptides $\mathbf{G 3}$ can form a hexagonal columnar liquid crystals over a wide temperature range.

\section{Experimental}

L-Aspartic acid and $N$-carbobenzyloxy-L-aspartic acid were purchased from Yangzhou Baosheng Bio-Chemical Co. Ltd. $N$-(3-Dimethylaminopropyl)- $N$ '-ethylcarbodiimide hydrochloride (EDCI), 4-dimethylaminopyridine and 1-hydroxy benzotriazole were purchased from Shanghai Medpep Co. Ltd. 1-Dodecanol and solvents were purchased from Sinopharm Chemical Reagent Co. Ltd, and used without any further purification. Solvents used for precipitation and column chromatography were distilled under normal atmospheric pressure. ${ }^{1} \mathrm{H}$ NMR spectra were recorded at $20^{\circ} \mathrm{C}$ on a $300 \mathrm{MHz}$ NMR spectrometer (Bruker). Chemical shifts are reported in ppm at room temperature in $\mathrm{CDCl}_{3}$ with tetramethylsilane as internal standard unless indicated otherwise. Mass spectra were carried out using MALDI-TOF/TOF matrix assisted laser desorption ionization mass spectrometry with Autoflex III Smartbeam (Bruker Daltonics Inc). Differential scanning calorimetry (DSC) was carried out with a Perkin Elmer differential scanning calorimeter (DSC7) with heating and cooling rates of $10 \mathrm{~K} / \mathrm{min}$. Phase transitions were also examined by a polarization optical microscope (POM) Olympus BX51 with a T95-PE temperaturecontrolled THMS-600 hot stage. X-ray diffraction measurements were performed on a D8 Advance (Bruker AXS Inc.) with $\mathrm{Cu} \mathrm{K \alpha 1:} 1.54051 \AA$. FT-IR spectra were recorded with a Varian 640 -IR in the range of $400-4000 \mathrm{~cm}^{-1}$. SEM measurement was performed with XL30 field emission scanning electron microscope.

G1: $2.67 \mathrm{~g} N$-carbobenzyloxy-L-aspartic acid (10.0 mmol) was dissolved in $60 \mathrm{~mL}$ of DCM. $4.79 \mathrm{~g}$ EDCI $(25.0 \mathrm{mmol})$ was added and the mixture stirred at $0{ }^{\circ} \mathrm{C}$ for $30 \mathrm{~min} .3 .72 \mathrm{~g}$ 1-Dodecanol $(20.0 \mathrm{mmol})$ and $0.25 \mathrm{~g}$ DMAP $(2.0 \mathrm{mmol})$ were added and the mixture stirred at room temperature for $24 \mathrm{~h}$. Solvent was removed by rotary evaporation. The residue was purified by column chromatography on silica gel with methylene chloride as the eluent to afford $\mathbf{G 1}$ as a white solid (5.32 g, 88\%). ${ }^{1} \mathrm{H}$ NMR (300 MHz, $\left.\mathrm{CDCl}_{3}, \delta\right)$ 7.36-7.30 (m, 5 $\mathrm{H}), 5.76(\mathrm{~d}, J=8.5 \mathrm{~Hz}, 1 \mathrm{H}), 5.14(\mathrm{~s}, 2 \mathrm{H}), 4.63(\mathrm{dd}, J=8.7 \mathrm{~Hz}$, $1 \mathrm{H}), 4.13(\mathrm{~d}, J=3.6 \mathrm{~Hz}, 2 \mathrm{H}), 4.06(\mathrm{t}, J=6.8 \mathrm{~Hz}, 2 \mathrm{H})$, $3.04-2.82(\mathrm{~m}, 2 \mathrm{H}), 1.63-1.57(\mathrm{~m}, 4 \mathrm{H}), 1.30-1.26(\mathrm{~m}, 36 \mathrm{H})$, $0.88(\mathrm{t}, J=7.1 \mathrm{~Hz}, 6 \mathrm{H})$. Anal. Calcd for $\mathrm{C}_{36} \mathrm{H}_{61} \mathrm{NO}_{6}: \mathrm{C}, 71.60$; $\mathrm{H}, 10.18 ; \mathrm{N}, 2.32$. found: $\mathrm{C}, 71.83 ; \mathrm{H}, 10.02 ; \mathrm{N}, 2.01 . \mathrm{m} / \mathrm{z}$ [MALDI-TOF]: $604.7\left(\mathrm{M}+\mathrm{H}^{+}\right)$.

G2: $1.335 \mathrm{~g} \mathrm{~N}$-carbobenzyloxy-L-aspartic acid (5 mmol) was dissolved in $60 \mathrm{~mL}$ of DCM, $2.880 \mathrm{~g}$ EDCI $(15 \mathrm{mmol})$ was added, and the mixture stirred at $0{ }^{\circ} \mathrm{C}$ for $30 \mathrm{~min} .7 .035 \mathrm{~g}$ L-Aspartic acid dodecyl ester $(15 \mathrm{mmol})$ and $2.280 \mathrm{~g} \mathrm{HOBt}$ (15 mmol) were added and the mixture stirred at room temperature for $24 \mathrm{~h}$. Solvent was removed by rotary evaporation. The crude product was purified by column chromatography on silica gel with methylene chloride:ethanol (100:1) as an eluent to afford G2 as a white solid (4.38 g, 75\%). ${ }^{1} \mathrm{H}$ NMR (300 MHz, $\left.\mathrm{CDCl}_{3}, \delta\right) 0.89\left(\mathrm{t}, 12 \mathrm{H}, \mathrm{CH}_{3}\right), 1.26\left(\mathrm{~s}, 72 \mathrm{H}, \mathrm{CH}_{2}\right), 1.62(\mathrm{~s}, 8 \mathrm{H}$, $\mathrm{CH}_{2}$ ), 2.64 (t, 2H, $\left.\mathrm{CH}_{2}\right), 2.81$ (m, 2H, $\left.\mathrm{CH}_{2}\right), 2.95-3.01(\mathrm{~m}, 2 \mathrm{H}$, $\left.\mathrm{CH}_{2}\right), 2.93-3.01\left(\mathrm{~m}, 8 \mathrm{H}, \mathrm{CH}_{2}\right), 4.59(\mathrm{~s}, 1 \mathrm{H}, \mathrm{CH}), 4.80(\mathrm{~s}, 2 \mathrm{H}$, $\mathrm{CH}), 5.13\left(\mathrm{~d}, 2 \mathrm{H}, \mathrm{CH}_{2}\right), 6.71(\mathrm{~s}, 1 \mathrm{H}, \mathrm{NH}), 6.73(\mathrm{~s}, 1 \mathrm{H}, \mathrm{NH})$, 7.29-7.36 (m, 5H, $\left.\mathrm{C}_{6} \mathrm{H}_{5}\right), 7.59(\mathrm{~s}, 1 \mathrm{H}, \mathrm{NH})$. Anal. Calcd for $\mathrm{C}_{68} \mathrm{H}_{119} \mathrm{~N}_{3} \mathrm{O}_{12}$ : C, 69.76; H, 10.25; N, 3.59. found: C, 70.04; $\mathrm{H}$, 10.06; N, 3.70. $\mathrm{m} / \mathrm{z}$ [MALDI-TOF]: $1192.8\left(\mathrm{M}+\mathrm{Na}^{+}\right)$

G3: $0.133 \mathrm{~g} N$-carbobenzyloxy-L-aspartic acid $(0.5 \mathrm{mmol})$ was dissolved in $30 \mathrm{~mL}$ of DCM, $0.288 \mathrm{~g}$ EDCI $(1.5 \mathrm{mmol})$ was added, and the mixture stirred at $0{ }^{\circ} \mathrm{C}$ for $30 \mathrm{~min} .1 .553 \mathrm{~g}$ of the second generation L-aspartic acid dodecyl ester $(1.5 \mathrm{mmol})$ and $0.228 \mathrm{~g} \mathrm{HOBt}(1.5 \mathrm{mmol})$ were added and the mixture stirred at room temperature for $24 \mathrm{~h}$. Solvent was removed by rotary evaporation. The crude product was purified by column chromatography on silica gel with methylene chloride:ethanol 
(100:3) as an eluent to afford $\mathbf{G 3}$ as a white solid (0.69 g, 60\%). ${ }^{1} \mathrm{H}$ NMR (300 MHz, $\left.\mathrm{CDCl}_{3}, \delta\right) 0.88$ (t, 24H, $\left.\mathrm{CH}_{3}\right), 1.29$ (s, $\left.144 \mathrm{H}, \mathrm{CH}_{2}\right), 1.59\left(\mathrm{~s}, 16 \mathrm{H}, \mathrm{CH}_{2}\right), 2.70\left(\mathrm{~s}, 8 \mathrm{H}, \mathrm{CH}_{2}\right), 2.83(\mathrm{~m}$, $\left.4 \mathrm{H}, \mathrm{CH}_{2}\right), 2.93\left(\mathrm{~m}, 2 \mathrm{H}, \mathrm{CH}_{2}\right), 4.02-4.12\left(\mathrm{~m}, 16 \mathrm{H}, \mathrm{CH}_{2}\right), 4.54$ $(\mathrm{s}, 1 \mathrm{H}, \mathrm{CH}), 4.82(\mathrm{~m}, 6 \mathrm{H}, \mathrm{CH}), 5.11\left(\mathrm{~s}, 2 \mathrm{H}, \mathrm{CH}_{2}\right), 6.32(\mathrm{~d}, 1 \mathrm{H}$, $\mathrm{NH}), 7.11(\mathrm{~m}, 2 \mathrm{H}, \mathrm{NH}), 7.26-7.36\left(\mathrm{~m}, 5 \mathrm{H}, \mathrm{C}_{6} \mathrm{H}_{5}\right), 7.69-7.97$ (m, $4 \mathrm{H}, \mathrm{NH})$. Anal. Calcd for $\mathrm{C}_{132} \mathrm{H}_{235} \mathrm{~N}_{7} \mathrm{O}_{24}$ : C, 68.80; $\mathrm{H}$, 10.25; N, 4.25. found: C, 68.55; H, 10.16; N, 4.51. $\mathrm{m} / \mathrm{z}$ [MALDI-TOF]: $2326.8\left(\mathrm{M}+\mathrm{Na}^{+}\right)$

\section{Acknowledgements}

This work was supported by the Science Research Project of Department of Education of Hebei Province (Nos.2007413), the National Natural Science Foundation of Hebei Province (Nos. B2007000146), the National Natural Science Foundation of China (Nos.20804012).

\section{References}

1. Gazit, E. Chem. Soc. Rev. 2007, 36, 1263-1269. doi:10.1039/b605536m

2. Yang, Z.; Liang, G.; Xu, B. Acc. Chem. Res. 2008, 41, 315-326. doi:10.1021/ar7001914

3. Ulijn, R. V.; Smith, A. M. Chem. Soc. Rev. 2008, 37, 664-675. doi:10.1039/b609047h

4. Vincent, J. F. V.; Currey, J. D., Eds. The mechanical properties of biological materials; Cambridge University Press: Cambridge, New York, 1980

5. Knowles, T. P.; Fitzpatrick, A. W.; Meehan, S.; Mott, H. R.; Vendruscolo, M.; Dobson, C. M.; Welland, M. E. Science 2007, 318, 1900-1903. doi:10.1126/science.1150057

6. Löwik, D. W. P. M.; van Hest, J. C. M. Chem. Soc. Rev. 2004, 33, 234-245. doi:10.1039/b212638a

7. Zhao, X.; Zhang, S. Trends Biotechnol. 2004, 22, 470-476. doi:10.1016/j.tibtech.2004.07.011

8. Cavalli, S.; Albericio, F.; Kros, A. Chem. Soc. Rev. 2010, 39, 241-263. doi:10.1039/b906701a

9. Tomalia, D. A.; Huang, B.; Swanson, D. R.; Brothers, H. M., II; Klimash, J. W. Tetrahedron 2003, 59, 3799-3813. doi:10.1016/S0040-4020(03)00430-7

10. Dandliker, P. J.; Diederich, F.; Gisselbrecht, J.-P.; Louati, A.; Gross, M. Angew. Chem., Int. Ed. Engl. 1996, 34, 2725-2728. doi:10.1002/anie.199527251

11. Ranganathan, D.; Kurur, S.; Gilardi, R.; Karle, I. L. Biopolymers 2000, 54, 289-295. doi:10.1002/1097-0282(20001005)54:4<289::AID-BIP60>3.0.CO;2-7

12. Choi, J. S.; Joo, D. K.; Kim, C. H.; Kim, K.; Park, J. S. J. Am. Chem. Soc. 2000, 122, 474-480. doi:10.1021/ja9931473

13. Ranganathan, D.; Kurur, S.; Madhusudanan, K. P.; Roy, R.; Karle, I. L. J. Pept. Res. 1998, 51, 297-302. doi:10.1111/j.1399-3011.1998.tb00427.x

14. Percec, V.; Dulcey, A. E.; Venkatachalapathy, S. K.; Balagurusamy, V. S. K.; Miura, Y.; Smidrkal, J.; Peterca, M.; Nummelin, S.; Edlund, U.; Hudson, S. D.; Heiney, P. A.; Duan, H.; Magonov, S. N.; Vinogradov, S. A. Nature 2004, 430, 764-768. doi:10.1038/nature02770
15. Nishii, M.; Matsuoka, T.; Kamikawa, Y.; Kato, T. Org. Biomol. Chem. 2005, 3, 875-880. doi:10.1039/b416474a

16. Kamikawa, Y.; Kato, T. Org. Lett. 2006, 8, 2463-2466. doi:10.1021/ol060580q

\section{License and Terms}

This is an Open Access article under the terms of the Creative Commons Attribution License

(http://creativecommons.org/licenses/by/2.0), which permits unrestricted use, distribution, and reproduction in any medium, provided the original work is properly cited.

The license is subject to the Beilstein Journal of Organic Chemistry terms and conditions:

(http://www.beilstein-journals.org/bjoc)

The definitive version of this article is the electronic one which can be found at: doi:10.3762/bjoc. 7.26 